Piotr Sygut ${ }^{1}$, Stanisław Borkowski ${ }^{2}$, Dorota Klimecka-Tatar ${ }^{3}$, Pawet Szklarzyk ${ }^{4}$

\title{
THE IMPORTANCE OF VISUAL INSPECTION IN FLAT PRODUCTS ROLLING PROCESS
}

\begin{abstract}
The importance of visual inspection in the production process is a very important factor, possibly due to the relatively rapid separation of defective products complying with standards. In order to improve the quality of ongoing processes companies choose preventive action, which are based on the first step to control various operations and finished products. The flat products rolling process is dependent on many factors (temperature charge / band, the rolling rhythm, the length of the band, interruption in the rolling mill, etc.) that affect the quality of the final product. Proper conduct the rolling process is therefore dependent on its control (including visual inspection) and the staff decisions properly, in cases of the disturbance. The paper presents results of studies conducted in one of the national flat products rolling mill. A survey was performed using the BOST method. It is a method in which Toyota's management principles are described characteristic factors. Respondents were asked to answer the question: "What is the most important factor in the visual control?".
\end{abstract}

Key words: visual inspection, rolling process, quality, BOST questionnaire, Toyota's management principles

\section{Introduction}

In order to improve the quality of ongoing processes companies choose preventive action, which are based on the first stage on the control of individual operations. Now, thanks to a visual inspection, eg it is possible to relatively fast separation of defective products from complying with the standards. The company supervises the process of

${ }^{1}$ Dr inż., Czestochowa University of Technology, Faculty of Management, Institute of Production Engineering, e-mail: piotr.sygut.wz@gmail.com.

${ }^{2}$ Prof. n. tech. i n. ekonom. dr hab. inż., Czestochowa University of Technology, Faculty of Management, Institute of Production Engineering, e-mail: bork@pcz.pl

${ }^{3} \mathrm{Dr}$ inż., Czestochowa University of Technology, Faculty of Management, Institute of Production Engineering, e-mail: klimt@ wip.pcz.pl

${ }^{4}$ Mgr inż., Czestochowa University of Technology, Faculty of Management, Institute of Production Engineering, e-mail: szklarzyk.pawel@o2.pl 
product quality control specialists perform Quality Assurance (BORKOWSKI S., KONSTANCIAK M., JAGUSIAK M. 2011, BORKOWSKI S., SYGUT P., MIELCZAREK K. 2011, BORKOWSKI S. 2012, BORKOWSKI S. 2012, ŁUNARSKI J. 2008).

The main types of inspections undertaken in enterprises include mainly (LUNARSKI J. 2008):

- control input or preoperative - as it relates to internal and external supply, and its range depends mainly on the relationship with suppliers (in the absence of inconvenience control at this stage can be reduced to a minimum),

- control in manufacturing processes or operations conducted by the operator by means of appropriate equipment, automatic and interoperational performed on separate positions by appropriately qualified and trained in this field controllers,

- final inspection or postoperative involving the examination of specific parameters or characteristics of the product after completion of the process.

On the other hand in terms of the ways in which the control can be divided into the following types:

- destructive inspection carried out on special samples produced at the same time with real products, under identical conditions, or by random sampling,

- uses non-destructive control of various types of measurement methods (eg. surface quality, the length of the angle) and kept on the parts catalog.

According to the distribution of the number of measured features distinguishes the following types of controls:

- one hundred percent (full),

- random variable with the process,

- random aimed at releasing the batch of finished products.

A very important indication of the conduct of sampling is that the principles of mathematical statistics and the principle of random sampling, otherwise the control proves ineffective. Sampling is based on 
the verification of randomly selected products and on this basis, decisions are made regarding the possibility of release specific deliverable or her arrest (LUNARSKI J. 2008).

The product life cycle usually divided into the following forms of quality control (HAMROL A. 2005):

- the design stage of the product - consists of assessing the compatibility of the resulting material the requirements of the clients or designers; usually relies on the use of comparative research market,

- the design stage of the process - the task is to verify the effectiveness of the methods used in obtaining the quality established in the project are the most common methods of simulation,

- the stage of manufacture of the product - its purpose is to examine the compatibility achieved partial product quality requirements enshrined in the design documentation.

The rolling process of flat products is realized in the rolling mills, steel mills which are departments or independent economic entities, equipped with complex machines and devices designed to implement this kind of process and perform other technological operations. Main division rolling mill depends on the temperature at which the process is carried out, so we can distinguish hot and cold rolling mills. In addition, mills divided according to the type produced assortment and the arrangement of rolling mills and their mutual cooperation (DYJA H., Mróz S., SYGUT P., SYGUT M. 2012, SyguT P. 2013). Hence the quality of rolled products depends on many factors (temperature charge/ band, the rolling rhythm, the length of the band, interruption in the rolling mill, etc.) (DyJa H., Mróz S., Sygut P., Sygut M. 2012, Mróz S., LABER K., Sygut P., Dyja H. 2013, MrÓz S., LABER K., Sygut P., Dyja H. 2012, Sygut P., LABER K., BorkowsKi S. 2012, Sygut P. 2013). Proper conduct the rolling process is therefore dependent on its control (including visual inspection) and the staff decisions properly in cases of appearance the disturbances (SYGUT P., KLIMECKA-TATAR D., 
SzKlarzyK P. 2013, SzKlarzyK P., Klimecka-Tatar D., Sygut P. 2013).

\section{BOST survey results}

A survey was performed using the method of BOST (BORKOWSKI S. 2012A, BORKOWSKI S. 2012B). It is a method in which Toyota's management principles are described characteristic factors. With a full list of questions contained in the questionnaire BOST has been selected one question, on the basis of which it was made the analysis of the company. The survey was completed by employees of the company in the steel sector in Poland. Respondents were asked to answer the question: What is the most important factor in visual inspection (E7). The task of the respondents was their choice to enter a number between $1-6$, with 6 marked the most important factor (Tab. 1).

Table 1. Answers to the question: "What is the most important factor in the control of visual?" According to the survey BOST

\begin{tabular}{|c|c|c|}
\hline $\begin{array}{c}\text { Indicating the } \\
\text { factors }\end{array}$ & Evaluation \\
\hline CS & Clean, order & \\
\hline EP & Flow & \\
\hline TI & Information boards & \\
\hline UP & Participation in production places & \\
\hline ME & Monitoring & \\
\hline GW & Graphical presentation of results & \\
\hline
\end{tabular}

Source: own study

Table 2 shows the numerical summary of the judgments, the factors E7 area in six-rating scale derived from respondents' answers. 
Table 2. Principle 7. Numerical combination of the factors' importance evaluation for E7 area

\begin{tabular}{|c|c|c|c|c|c|c|}
\hline \multirow{2}{*}{ Evaluation } & \multicolumn{7}{|c|}{ Indicating the factors' } \\
\cline { 2 - 7 } & CS & EP & TI & UP & ME & GW \\
\hline $\mathbf{1}$ & 0 & 0 & 2 & 3 & 5 & 8 \\
\hline $\mathbf{2}$ & 1 & 3 & 5 & 2 & 3 & 4 \\
\hline $\mathbf{3}$ & 6 & 5 & 4 & 0 & 2 & 1 \\
\hline $\mathbf{4}$ & 3 & 1 & 5 & 5 & 2 & 2 \\
\hline $\mathbf{5}$ & 1 & 7 & 1 & 1 & 6 & 2 \\
\hline $\mathbf{6}$ & 7 & 2 & 1 & 7 & 0 & 1 \\
\hline
\end{tabular}

Source: own study

In turn, the structure as the percentage ratings of validity factors E7 region are shown in Table 3.

Table 3. Principle 7. Evaluation structure [\%] of the factors' importance for E7 area

\begin{tabular}{|c|c|c|c|c|c|c|}
\hline \multirow{2}{*}{ Evaluation } & \multicolumn{7}{|c|}{ Indicating the factors' } \\
\cline { 2 - 7 } & CS & EP & TI & UP & ME & GW \\
\hline $\mathbf{1}$ & 0 & 0 & 11.11 & 16.67 & 27.78 & 44.44 \\
\hline $\mathbf{2}$ & 5.56 & 16.67 & 27.78 & 11.11 & 16.67 & 22.22 \\
\hline $\mathbf{3}$ & 33.33 & 27.78 & 22.22 & 0 & 11.11 & 5.56 \\
\hline $\mathbf{4}$ & 16.67 & 5.56 & 27.78 & 27.78 & 11.11 & 11.11 \\
\hline $\mathbf{5}$ & 5.56 & 38.89 & 5.56 & 5.56 & 33.33 & 11.11 \\
\hline $\mathbf{6}$ & 38.89 & 11.11 & 5.56 & 38.89 & 0 & 5.56 \\
\hline
\end{tabular}

Source: own study

On the basis of the results of research using BOST survey noted that the most important factor in the control of the respondents have identified visual flow and cleanliness and order. Distribution of votes on the impact 
of various factors on visual inspection is shown in the graphs radar (Fig. 1).
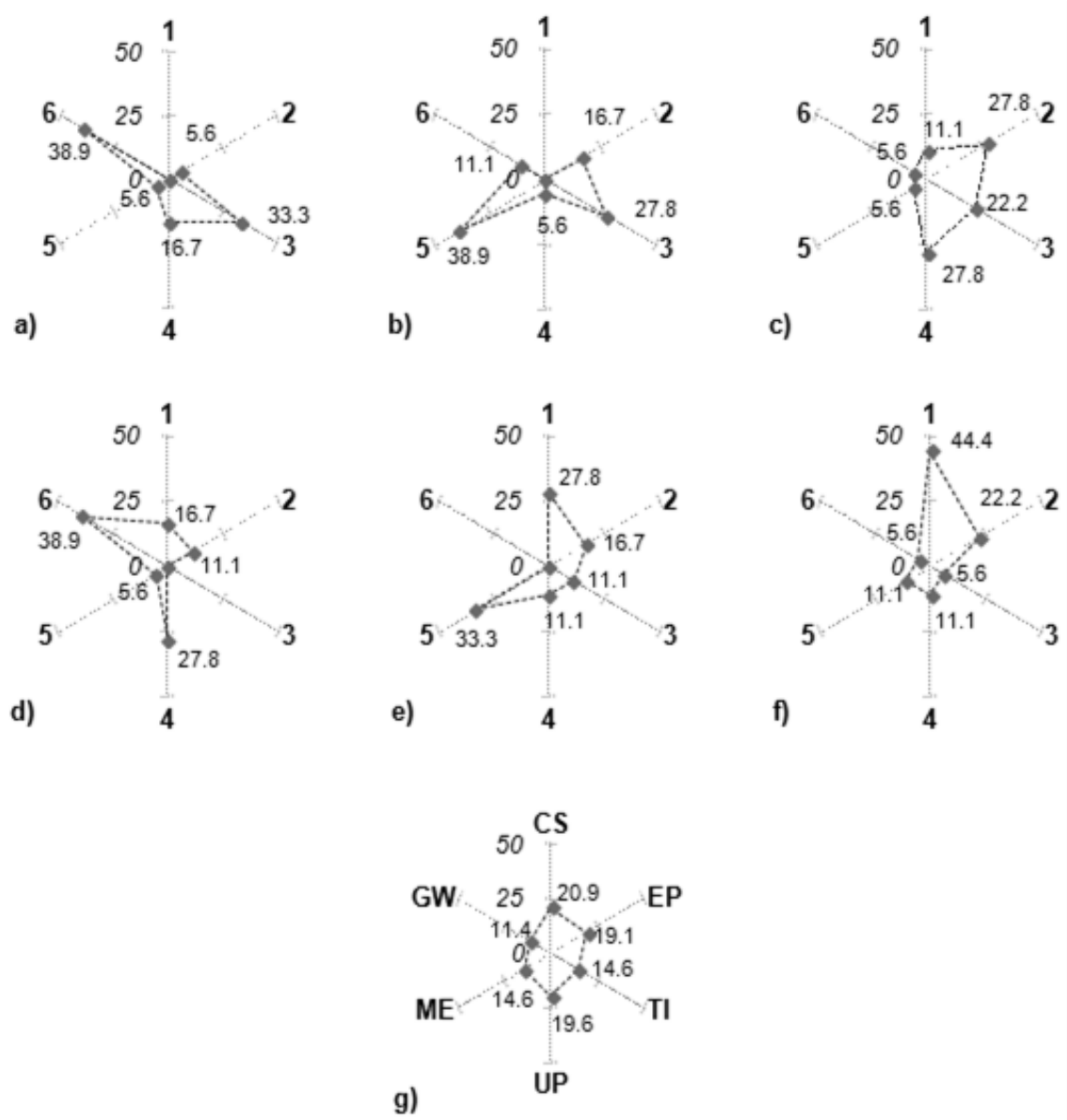

Fig. 1. Principle 7. Radar graphs - evaluation structure of the factors' importance for $\mathrm{E} 7$ area: a) $\mathrm{CS}, \mathrm{b}) \mathrm{EP}, \mathrm{c}) \mathrm{TI}, \mathrm{d}) \mathrm{UP}, \mathrm{e}) \mathrm{ME}, \mathrm{f}) \mathrm{GW}, \mathrm{g}$ ) average. Source: own study 
When assessing the validity of the factor: cleanliness and order (CS) appearing in Figure 1a can be seen that the most common assessment was 6 with $38.9 \%$ share of the total . Subsequently $33.3 \%$ of the total admitted rated 3, while $16.7 \%$ rated 4 . Evaluation 5 was given in $5.6 \%$, while there was no assessment 1.

While taking into account factors: flow (EP) (Fig. 1b ) can be noted that $38.9 \%$ of respondents indicated on a rating of 5 , while $27.8 \%$ marked the third assessment. Evaluation 2 and 6 are allocated at a level of $16.7 \%$ and $11.1 \%$. None of the respondents not allocated assessment 1 , and 5.6 $\%$ indicated an assessment of 4 .

Focusing on the factor: information boards (TI) (Fig. 1c) can be stated that the most popular articles were 2 and 4 , with $27.8 \%$ share each, and grade 3, which in turn indicated $22.2 \%$ of the surveyed employees. Evaluation 1 was given to $11.1 \%$ of the total responses. Least likely respondents marked Rating: 5 and 6, because in each case the same amount of votes , it is $5.6 \%$.

Analysing the results of the data presented in Figure 1d, participation in production (UP) received a rating of 5 majority (38.9\% of the total). A relatively large number of votes was also addressed in the assessment of $1(27.8 \%)$. The other ratings were characterized by participation, in turn, the following: evaluation of $2-16.7 \%$, evaluation 1 and $4-11.1 \%$ each in turn. There were however in no case indicate the assessment 6 .

The data in Figure 1e shows in turn that, when assessing the validity of the monitoring agent (ME) was dominated by two extreme groups of ratings, namely: grade $5-33.3 \%$, and $1-27.8 \%$. There were however of assessment 6 .

When assessing the validity of the factor graphical presentation of results (GW) (Fig. 1f ) can be noted that the assessment was by far the dominant one $(44.44 \%)$. Another note, it pointed to the employees was $2(22.2 \%)$. Respondents for this factor rarely used high grades: $6-5.6 \%$, 4 and $5-11.1 \%$, and $3-5.6 \%$.

According to the data presented in Figure 1g shows that for $20.9 \%$ of employees participating in the survey the most important factor is the 
cleanliness, order, for 19,6\% participation in places production, while for $19.1 \%$ of the flow. Received the lowest marks while the graphical presentation of the results of the $11.4 \%$ share of the votes and $14.6 \%$ of agents monitoring and information boards.

Figure 2 shows graphically the results of studies that allow comparison of both medium as well as the standard deviation and variance, and coefficients: skewness, variation and kurtosis for individual factors belonging to the area of E7.

Considering factors as statistical evaluations E7 area in this enterprise, it can be concluded that, taking into account the average (Fig. 2a) was rated highest factor cleanliness and order (average 4.39), while the least important was a graphical presentation of the results (average 2.39).

In the case of the standard deviation (Fig. 2b), the most important factor turned out to participate in production places showed its the highest level (1.94), while the evaluation factor signboards were most similar to each other (1.35). Deviation quartered (Qx), characterized by statistically $50 \%$ of the value of the central set also has the highest value (3.00) for the evaluation of the same factor as the standard deviation. 

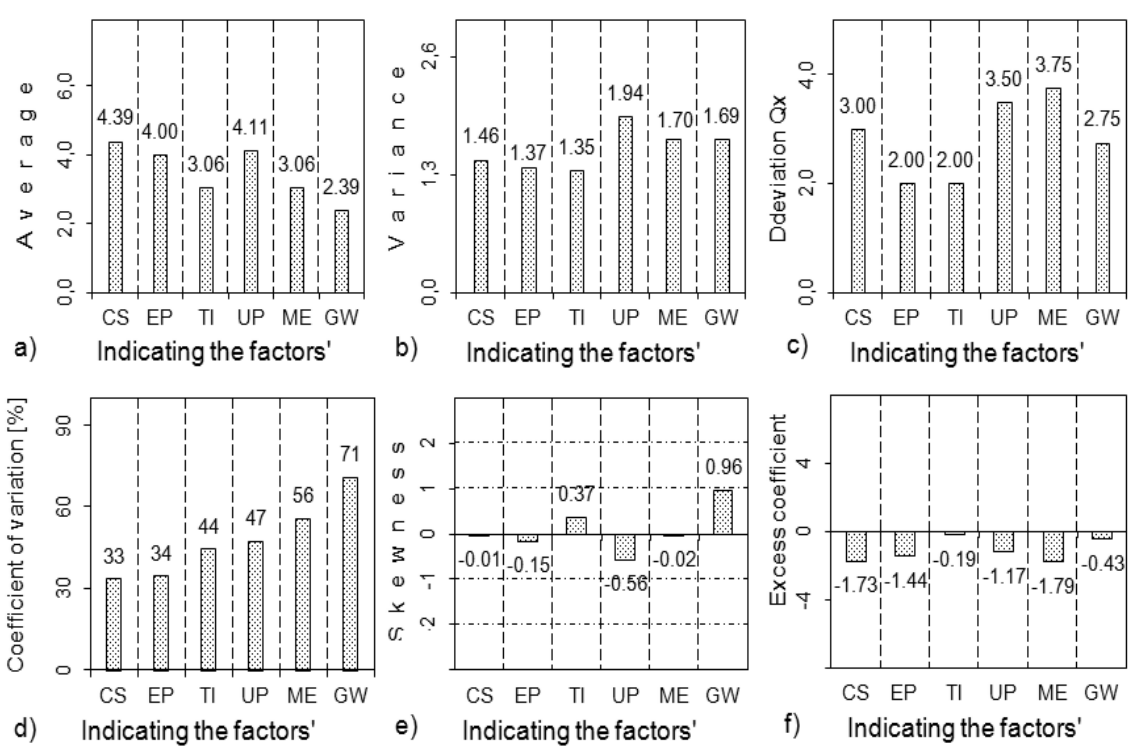

Fig. 2. Principle 7. Comparison: a) average, b) standard deviation, c) variance, d) coefficient of variation, e) skewness, $f$ ) kurtosis for E7 area factors.

Source: own study

The coefficient of variation (Fig. 2d) shows that the number of ratings for the entire scale was at a similar level most for the factor graphical presentation of the results $(71 \%)$. Number of ratings factor validity of cleanliness, order the most was varied group of subjective factors $(38 \%)$. The data in Figure $2 \mathrm{e}$ show that the ratings obtained for two sets of parameters (the symbols TI and GW) showed a left skewness, but all are more flattened than the set normal (Fig. 2f).

\subsection{Conclusion}

Over the past few years we have seen a deepening crisis steel industry. On the one hand, in its current form, the world can not function without steel products, on the other hand, competition is huge. Therefore, 
the only chance of metallurgical enterprises to increase their competitiveness by improving the quality of the product. At the moment decreasing demand is natural lowering prices of their goods, but the production costs can be reduced only to a specified threshold, while the right path beyond the price tag is targeting to increase its level of quality. In the process of rolling flat products quality control is an essential element, of which the one component of the whole process is a visual inspection. During the work has been thoroughly analyzed the importance of the process of control. The research results of the BOST survey found that during the visual inspection in the process of rolling flat products the most important elements are: cleanliness, order (in the understanding of $5 \mathrm{~S}$ practices) and participation in production places. Examined the company presents a high level of quality of our products and delivery of services, but there are areas that require continuous monitoring. In the current phase of the suggested solution for the company would invest in a wide-ranging quality, because only through continuous improvement is possible to eliminate competition and gain a competitive advantage in the market.

\section{Bibliography}

1. Borkowski S., KonstanciaK M., JagusiaK M. 2011. Standaryzacja $i$ kontrola wizualna jako podstawa ciagtej poprawy $w$ wybranym przedsiębiorstwie. Wybrane zagadnienia produkcji $\mathrm{i}$ zarządzania $\mathrm{w}$ przedsiębiorstwie. Pr. zbior. pod red. Jerzego Siwki. Wyd.WIPMiFS PCzęst. Częstochowa.

2. Borkowski S., Sygut P., MielcZAReK K. 2011. Functioning of the controls automotive parts production. Toyotarity. Control in organizations. Editing and Scientific Elaboration Borkowski S., Czajkowska A. Publisher Yurii V. Makovetsky. Dnipropetrovsk.

3. BoRKowsKi S. 2004. Mierzenie poziomu jakości. Wydawnictwo Wyższej Szkoły Zarządzania i Marketingu w Sosnowcu. Sosnowiec. 
4. BoRKOWSKI S. 2012A. Toyotaryzm. Wyniki badań BOST. Wydawnictwo Menedżerskie PTM. Warszawa.

5. BORKOWSKI S. 2012B. Zasady zarzadzania Toyoty w pytaniach. Wyniki badań BOST. Oficyna Wydawnicza PTM. Warszawa.

6. Dyja H., Mróz S., SYgUt P., SYGUT M. 2012. Technologia i modelowanie procesu walcowania prętów okragtych o zawężonej tolerancji wymiarowej. Wydawnictwo Wydziału Inżynierii Procesowej, Materiałowej i Fizyki Stosowanej Politechniki Częstochowskiej, Seria: Monografie Nr 27.

7. HAMrol A. 2008. Zarządzanie jakościa z przyktadami. PWN, Warszawa 2005.

8. ŁUNARSKI J. 2008. Zarządzanie jakościq. Standardy i zasady. Wydawnictwo Naukowo-Techniczne, Warszawa.

9. Mróz S., LABer K., Sygut P., DYja H. 2013. Analysis of the temperature change over the continuous ingot length on the parameters of round bar rolling process. METALURGIJA 1, vol. 52, Zagreb, Sijecanj-Ozujak. January-March 2013.

10. Mróz S., Laber K., SYgut P., Dyja H. 2012. Effect of temperature distribution over the feedstock length on the metal plastic flow during rod rolling. Steel Research International, Proceedings of the 14th Inernational Conference on Metal Forming, Metal Forming 2012, Kraków.

11. Sygut P., Klimecka-Tatar D., SzklarzyK P. 2013. Round Bars Production Process Improvement Including the Toyota Management Principles. Toyotarity. Evoluation and Processes'/Products' Improvement. Monograph. Scientific Editors Stanisław Borkowski, Manuela Ingaldi.

12. SYGUT P., LABER K., BORKOWSKI S. 2012. Investigation of the non-uniform temperature distribution on the metallic charge length during round bars rolling process. MANUFACTURING TECHNOLOGY, JOURNAL FOR SCIENCE, RESEARCH AND PRODUCTION. DECEMBER 2012. Vol. 12, No 13.

13. SYGUT P. 2013. Investigation of influence of non-uniform temperature change on the metallic charge length during industrial plain round bars rolling process. Quality control meaning in products and processes improvement. Monography. Editing and Scientific Elaboration Stanisław 
Borkowski, Piotr Sygut. Oficyna Wydawnicza Stowarzyszenia Menedżerów Jakości i Produkcji (SMJiP) and Faculty of Logistics, University of Maribor, Celje.

14. SzKlarzyK P., Klimecka-Tatar D., Sygut P. 2013. The Meaning of Toyotaryzm in Improving of the Hot-Rolled Plates Production Process. Toyotarity. Management of the Production Values. Monography. Scientific Editors Stanisław Borkowski, Tomislav Grladinović. 